\title{
Transcriptome analysis of alcohol-treated microglia reveals downregulation of beta amyloid phagocytosis
}

Sergey Kalinin ${ }^{1}$, Marta González-Prieto ${ }^{2}$, Hannah Scheiblich ${ }^{3}$, Lucia Lisi ${ }^{4}$, Handojo Kusumo ${ }^{5}$, Michael T. Heneka ${ }^{3}$, Jose L. M. Madrigal ${ }^{2}$, Subhash C. Pandey ${ }^{5,6}$ and Douglas L. Feinstein ${ }^{1,6^{*}}$

\begin{abstract}
Background: Microglial activation contributes to the neuropathology associated with chronic alcohol exposure and withdrawal, including the expression of inflammatory and anti-inflammatory genes. In the current study, we examined the transcriptome of primary rat microglial cells following incubation with alcohol alone, or alcohol together with a robust inflammatory stimulus.

Methods: Primary microglia were prepared from mixed rat glial cultures. Cells were incubated with $75 \mathrm{mM}$ ethanol alone or with proinflammatory cytokines ("TII": IL1 $\beta$, IFNY, and TNFa). Isolated mRNA was used for RNAseq analysis and GPCR. Effects of alcohol on phagocytosis were determined by uptake of oligomeric amyloid beta.

Results: Alcohol induced nitrite production in control cells and increased nitrite production in cells co-treated with TII. RNAseq analysis of microglia exposed for $24 \mathrm{~h}$ to alcohol identified 312 differentially expressed mRNAs ("AlcDEs"), with changes confirmed by qPCR analysis. Gene ontology analysis identified phagosome as one of the highest-ranking KEGG pathways including transcripts regulating phagocytosis. Alcohol also increased several complement-related mRNAs that have roles in phagocytosis, including C1qa, b, and c; C3; and C3aR1. RNAseq analysis identified over 3000 differentially expressed mRNAs in microglia following overnight incubation with TIl; and comparison to the group of Alc-DEs revealed 87 mRNAs modulated by alcohol but not by TII, including C1qa, b, and c. Consistent with observed changes in phagocytosis-related mRNAs, the uptake of amyloid beta $_{1-42}$, by primary microglia, was reduced by alcohol.
\end{abstract}

Conclusions: Our results define alterations that occur to microglial gene expression following alcohol exposure and suggest that alcohol effects on phagocytosis could contribute to the development of Alzheimer's disease.

Keywords: Alcohol, Phagocytosis, Complement, Alzheimer's disease, Amyloid, Microglia

\section{Background}

Microglial activation occurs in a variety of neurological conditions and diseases, and increasing number of studies show that microglial activation contributes to the neuroinflammation associated with chronic alcohol exposure and withdrawal. Studies indicate that innate immune signaling plays a role in alcohol addiction, and genes implicated in neuroinflammatory processes accompanying alcoholism

\footnotetext{
*Correspondence: dlfeins@uic.edu

'Department of Anesthesiology, University of Illinois at Chicago, Chicago, IL 60612, USA

${ }^{6}$ Department of Veterans Affairs, Jesse Brown VA Medical Center, Chicago, IL 60612, USA

Full list of author information is available at the end of the article
}

are expressed in microglia [1-3]. Supporting a role for microglial activation are studies showing that treatment with minocycline, which selectively reduces microglia activation, reduces alcohol intake as well as acute actions of ethanol on sedation and motor impairment $[4,5]$, and similarly, treatment of mice with tigecycline, another tetracycline derivative, reduced alcohol consumption and clinical features of alcohol consumption in mice [6]. There are also increasing studies demonstrating that microglia can be directly activated by alcohol leading to increases in inflammatory factors including cytokines, chemokines, transcription factors, and their receptors [1, 2, 7-13]. In many cases, the effects of alcohol were shown to involve

(C) The Author(s). 2018 Open Access This article is distributed under the terms of the Creative Commons Attribution 4.0 International License (http://creativecommons.org/licenses/by/4.0/), which permits unrestricted use, distribution, and 
activation of the Tlr4 receptor $[9,10,12,14-17]$ which can directly activate inflammatory transcription factor NFkB and subsequently increase of inflammatory gene expression. Alcohol has also increased the expression of TLRs, in both the liver [18] and the CNS [19, 20]. Other studies have shown that alcohol also increases expression and acetylation of HMGB1 which can bind to TLRs and thereby induce inflammatory gene expression $[3,19]$.

Despite the above studies that focused on specific genes or categories of genes, there are few papers which provide characterization of the microglial transcriptome following alcohol treatment or consumption. Transcript profiling has been carried out using RNA from whole brain [4], amygdala [21], prefrontal cortex [22], and nucleus accumbens [23] from alcohol-fed mice. While pathway analysis identified many microglial associated functions, only a single study has directly examined the transcriptome of microglia acutely isolated from cortex of alcohol-fed mice [24]. In that study, over 400 transcripts were identified in the microglial that were not present in pre-frontal cortical RNA [22], suggesting that cell type enrichment is necessary to fully characterize the effects of alcohol on the microglial transcriptome.

While microglial activation and increased proinflammatory cytokine and chemokine expression can initiate or exacerbate ongoing pathology, microglia also perform beneficial actions that limit damage in neurological diseases and conditions. Microglial-mediated processes are a key determinant to the accumulation of amyloid deposits in AD (and its mouse models), playing roles in amyloid degradation (by metalloproteases including neprilysin and insulin degrading enzyme), in removal of amyloid by phagocytosis, and by initiation and growth of plaques (involving seeding by microglial inflammasome activation) [25]. Dysregulation of these processes will alter the balance between amyloid production and clearance, with the net result of increased amyloid burden. In Alzheimer's disease (AD), microglial phagocytosis of oligomeric and aggregated forms of amyloid beta $(A \beta)$ is one of the key means by which amyloid burden is limited [26, 27]. Several studies suggest that alcohol may be a risk factor for $\mathrm{AD}$ [28-31], and there are also reports that alcohol increases amyloid processing and deposition [32-34]. However, whether alcohol influences the ability or efficacy of microglial cells to internalize $A \beta$ has not been examined, although several studies have shown that peripheral macrophages have reduced phagocytotic activity after alcohol treatment $[35,36]$.

In the current study, we evaluated the acute effects of alcohol on inflammatory responses in primary rat microglial cells using RNAseq analysis to define the changes in gene expression due to alcohol. Our results define alterations in microglial mRNA expression following exposure to alcohol and suggest that alcohol consumption may represent a risk factor for development of amyloid burden.

\section{Methods \\ Primary microglial cells}

All studies with animals were approved by the UIC Institutional Animal Care and Use Committee. Primary mixed glial cells were prepared from the frontal cortices of grouped male and female post-natal day 2 Sprague Dawley rats from the same litter [37]. In brief, cerebral cortices were cleaned from all meninges, digested in trypsin, and dissociated into single cell suspension by trituration through syringes. The cells were plated onto poly-L-lysine-coated flasks and grown in Dulbecco's modified Eagle's media (DMEM) supplemented with $10 \%$ heat inactivated fetal bovine serum (FBS) and 1\% antibiotics (P/S; penicillin/streptomycin, Gibco, ThermoFisher, Waltham, MA, USA). The next day, cells were washed with $\mathrm{PBS}$ to remove debris, and the media were changed twice per week. After 7-10 days, loosely attached microglia were removed from underlying astrocytes by shaking flasks at 220 RPM for $30 \mathrm{~min}$ at $37{ }^{\circ} \mathrm{C}$. Cells were collected, replated into dishes in DMEM containing 10\% FBS and $1 \% \mathrm{P} / \mathrm{S}$, and allowed to adhere overnight. The next day, the media were changed to serum free DMEM with $1 \%$ $\mathrm{N}-2$ supplement.

\section{Alcohol and cytokine treatment}

Microglia were exposed to ethanol in incubator chambers (Modular Incubator Chambers MIC-101, BillupsRothenberg Inc. Del Mar, CA) containing either $100 \mathrm{~mL}$ ddH2O alone or $75 \mathrm{mM}$ ethanol. Ethanol was added directly to the cell media to bring the final concentration to $75 \mathrm{mM}$. The chambers were flushed with $5 \% \mathrm{CO}_{2}, 21 \%$ $\mathrm{O}_{2}$, balanced nitrogen mixture from a compressed air tank at $0.5 \mathrm{psi}$ for $4 \mathrm{~min}$, and then incubated at $37^{\circ} \mathrm{C}$ for $24 \mathrm{~h}$. Where indicated, a mixture of pro-inflammatory cytokines ("TII", TNF $\alpha, 10 \mathrm{ng} / \mathrm{ml}$; IL- $1 \beta, 10 \mathrm{ng} / \mathrm{ml}$; and IFN $\gamma, 10 \mathrm{IU} / \mathrm{ml}$ ) dissolved in cell culture media was added to the cells to induce an inflammatory response; control cells received the equivalent volume of cell culture media.

\section{Phagocytosis assay}

Phagocytosis was assessed in rat primary microglial cells. For this, the cell culture media was first changed to serum-free DMEM supplemented with $1 \% \mathrm{~N}-2$ supplement (Gibco). After $24 \mathrm{~h}$, cells $\left(3.5 \times 10^{5}\right.$ cells/well) were incubated under control conditions or in medium containing $75 \mathrm{mM}$ EtOH, TII, or TII with $75 \mathrm{mM}$ EtOH. After $24 \mathrm{~h}$, the medium was replaced with fresh medium (control or containing $75 \mathrm{mM} \mathrm{EtOH}$ ) supplemented 
with 6-carboxyfluorescein (FAM)-labeled $A \beta_{1-42}(0.5 \mu \mathrm{M}$; Anaspec, Fremont, CA, USA). The A $\beta$ peptide was dissolved in DMSO to obtain a 0.1-mM stock, diluted into DMEM to a final concentration of $500 \mathrm{nM}$, then incubated at $37^{\circ} \mathrm{C}$ for $1 \mathrm{~h}$ to promote aggregation. Cells were incubated for indicated times, followed by one washing with PBS to remove $A \beta$, then harvested using $0.5 \%$ Trypsin (Gibco). Blocking solution containing PBS and FBS (1:1 ratio) was applied for $10 \mathrm{~min}$ on ice. Cells were collected, resuspended in $400 \mu$ ice cold FACS solution (PBS supplemented with 2\% FCS), and measured by flow cytometry using the Gallios software (Beckman Coulter's). Phagocytosis was analyzed and quantified for total uptake and for the percentage of cells with internalized $A \beta$, using Flowing Software (University of Turku, Finland).

\section{Nitrite production}

Inflammatory activation of microglia was assessed indirectly as the production of nitrites in the cell culture media, an index of the induction of nitric oxide synthase type 2, measured using Griess reagent. Background values were obtained using media only and were subtracted from values obtained using cells.

\section{RNA isolation}

RNA was isolated using Direct-zol RNA MicroPrep (Zymo Research, Irvine, CA, USA) according to instructions. The resulting RNA quality was determined using the 4200 TapeStation Instrument (Agilent, Santa Clara, CA), and all samples had RNA integrity numbers (RIN) above 8 .

\section{Library generation}

Illumina compatible libraries were prepared from RNA using QuantSeq 3' mRNA-seq Library Prep Kit FWD for Illumina (Lexogen $\mathrm{GmbH}$, Wien, Austria) according to the manufacturer's instructions. In brief, library generation was initiated by oligo-dT priming and first-strand synthesis. After RNA removal, libraries were subjected to random-primed second-strand synthesis. Illumina specific linker sequences are added by the primer, and the resulting double-stranded cDNA purified with magnetic beads. An additional 12 cycles of PCR amplification were carried out in order to introduce barcodes and to generate sufficient amounts of DNA required for cluster generation. After final purification, libraries were measured on TapeStation and Qubit (ThermoFisher, Waltham, MA) to determine quantity and size. The resulting libraries were on average 400-bp size with an average insert size of $270 \mathrm{bp}$. The method does not require prior poly(A) enrichment or ribosomal RNA depletion. ERCC (External RNA Controls Consortium) RNA Spike-In Mix (Cat\# 4456740 Thermo Fisher Scientific, Waltham,
MA) was added to the RNA before library preparation to allow inter-sample normalization and control for variabilities.

\section{RNA sequencing and analysis}

Barcoded libraries were pooled and sequenced on Illumina NextSeq system (Illumina, San Diego, CA, USA) producing about $500 \mathrm{M}$ reads of non-paired 75-nt sequence. Up to 32 barcoded samples were pooled together producing on average $12 \mathrm{M}$ reads per sample. RNAseq analysis was carried out using the BaseSpace platform from Illumina. The RNAseq-generated FASTQ files were aligned to the USCSrn5 Rattus norvegicus reference genome with STAR aligner [38] with allowed mismatches set to 14. Differentially expressed (DE) mRNAs were determined using the DeSeq2 package based on the negative binomial distribution and a false discovery rate of $0.1 \%$ [39]. In brief, paired RNAseq data for each transcript are compared using Wald testing which is a more powerful method than others to detect significant differences in low expression transcripts [40]; those with Wald $p$ values $<0.05$ are ordered, and an adjusted $p$ value is then determined using Benjamini-Hochberg approach to minimize false discovery to $0.1 \%$ or less. This method does not take into consideration the magnitude of the difference in expression. Functional and pathway analysis were performed using DAVID [41] and GO Consortium [42, 43] platforms.

\section{Quantitative real-time PCR}

Whole cell RNA $(1 \mu \mathrm{g})$ was converted to cDNA using the High Capacity cDNA Reverse Transcription Kit (Applied Biosystems cat \#4368814, ThermoFisher, Waltham, MA, USA). The cDNA was amplified using FastStart Universal SYBR Green Master mix (Applied Biosystems, cat \#04913914001, Foster City, CA, USA) in a Corbett RotoGene real-time PCR machine (Qiagen, Germantown, MD). The relative levels of mRNA were calculated from threshold take-off cycle number and normalized to values measured for $\beta$-actin in the same samples.

\section{Data analysis}

Data are presented as mean \pm SEM of at least three independent experiments. qPCR data were compared using Student's $t$ tests. Nitrite data were compared using oneway parametric ANOVA and Tukey's post hoc comparisons. Phagocytosis data were analyzed for Gaussian distribution; all data passed normality test so comparisons were performed with one-way ANOVA and Tukey's post hoc comparisons. 


\section{Results}

Alcohol increases microglial inflammatory activation Enriched (>95\%) primary microglia were prepared by the shake-off method from postnatal day 2 rat cortical mixed glial cultures, then incubated with $75 \mathrm{mM}$ ethanol, with or without TII to induce inflammatory activation as assessed by measurement of nitrite levels in the culture media. Under these conditions, ethanol alone increased nitrite levels about twofold above control values (Fig. 1). Incubation with TII increased nitrite production about threefold over control, and that was further increased (to about fourfold control values) when ethanol was present.

\section{Alcohol-dependent changes in microglial mRNA}

RNAseq analysis was used to identify mRNAs regulated by exposure to alcohol. Of 17,327 genes in the rat reference genome, 15,062 mRNAs were identified having over 0.1 FPKM (Additional file 1: Table S6); of those, 312 were differentially expressed (DE) following ethanol treatment ("Alc-DEs"; Additional file 1: Table S1). The majority of Alc-DEs (230) were increased, while 82 were decreased by ethanol. Of those, 274 were changed by at least $20 \%$ and 19 changed by at least $50 \%$. Gda (guanine deaminase) was the mRNA most decreased (to about 50\% of control values), and Robo1 (roundabout guidance receptor 1) and Plxdc2 (plexin domain containing 2) were the most increased (to $170 \%$ of control values) by alcohol. Quantitative reverse-transcription PCR (qPCR) of the mRNAs showing the largest changes, as well as of several other mRNAs selected for having important functional consequences, validated RNAseq results (Fig. 2).

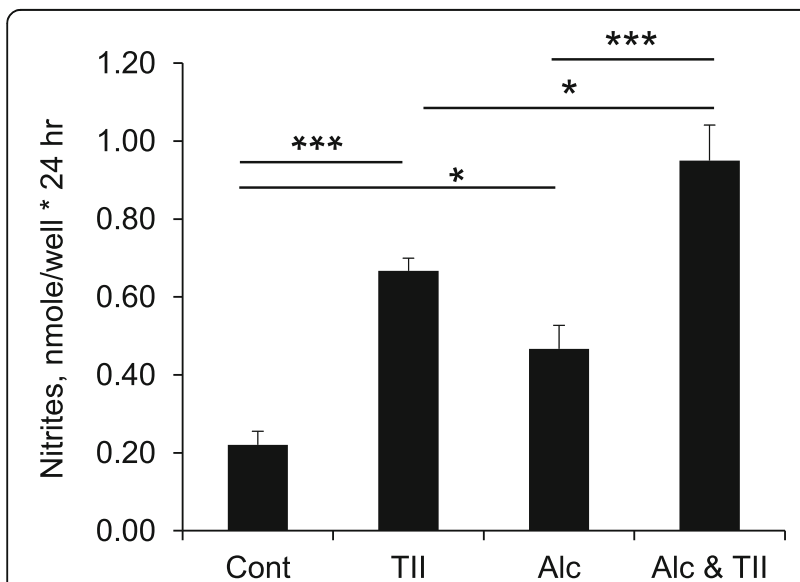

Fig. 1 Alcohol increases microglial inflammatory activation. Primary rat microglia were incubated overnight with nothing (control), with TIl to induce an inflammatory response, with $75 \mathrm{mM}$ ethanol (Alc), or with TII and ethanol (Alc and TII). The next day, nitrite production was measured using Griess reagent. The data is the mean \pm sem of $n=6-15$ replicates done in 3 independent studies. ${ }^{*} P<0.05$; ${ }^{* *} P<$ 0.0001; one-way ANOVA, Tukey's post hoc analysis
To compare microglial responses to alcohol to those elicited by an inflammatory stimulus, we carried out RNAseq on RNA from TII-treated microglia. In contrast to alcohol, there was a dramatic alteration in mRNA expression due to this robust stimulus. Using the same criteria ( $P$ values adjusted for an FDR of $<0.1 \%$ ), we identified 3082 mRNAs modified by TII ("TII-DEs"; Additional file 1: Table S2). Of those, 1266 were changed by over 50\%; 43 mRNAs increased over 10-fold; and 21 decreased by at least 10 -fold. To determine how alcohol influences microglial gene expression in the context of inflammation, we carried out RNAseq of mRNA from cells treated with TII together with ethanol. A total of 3552 mRNAs were identified ("AlcTII-DEs", Additional file 1: Table S3), slightly more than that due to TII alone. Of those, 1432 were changed by over $50 \%, 53$ mRNAs were increased over 10 -fold, and 25 were decreased by at least 10-fold.

Comparison (Fig. 3 and Additional file 1: Table S4) of Alc-DEs (regions 1, 2, 4, and 5) to TII-DEs (regions 2, 3, 5 , and 6) shows that 225 of the 312 Alc-DEs are present in both groups (regions 2 and 5). The remaining 87 Alc-DEs (regions 1 and 4) are not induced by a robust inflammatory stimulus; therefore, these represent a noncanonical type of microglial activation; we refer to this group as Alc*-DEs. Further comparison to the AlcTIIDE group shows that 21 DEs ("AlcOnly-DEs", region 1) are found only in the Alc-DE group. Comparison of AlcTII-DEs to TII-DEs shows considerable overlap (2601 DEs, regions 5 and 6) between these two groups; as well as an additional 951 ("AlcInf-DEs", regions 4 and 7) that are not detected in the TII group. Of those 951 AlcInf-DEs, 885 ("Alc*TII-DEs", region 7) are increased by alcohol only in the context of inflammation but not by alcohol or by TII alone.

Gene Ontology analysis (DAVID) identified five KEGG pathways enriched in the 312 Alc-DE group (Additional file 1: Table S5A), with one of the highest categories being phagosome containing 15 transcripts (Atp6ap1, C3, Calr, Coro1a, Ctss, Cyba, Fcgr1a, Itgb5, Ncf1, RT1-A1, RT1-CE14, RT1-N3, RT1-S3, Tuba1b, and Tlr2). In addition, a Gene Ontology Consortium analysis [42, 43] identified a ninefold enrichment in transcripts involved in regulation of phagocytosis including Psap, Pycard, CD300lf, Slc11a1, Mfge8, and Sirpa. DAVID analysis of the 21 AlcOnly-DEs did not identify any enriched GO terms or KEGG pathways likely due to the small group size. However, four members (C1qb, Ifih1, Ly86, and Tmem30a) play roles in the innate immune system and Tlr4 signaling, and three members (Laptm5, Map1Lc3a, and Uba7) are involved in protein degradation. In the group of 87 alcohol-specific Alc*-DEs, only endoplasmic reticulum (ER) was identified as an enriched cytosolic component. However, this group includes all 3 isoforms 


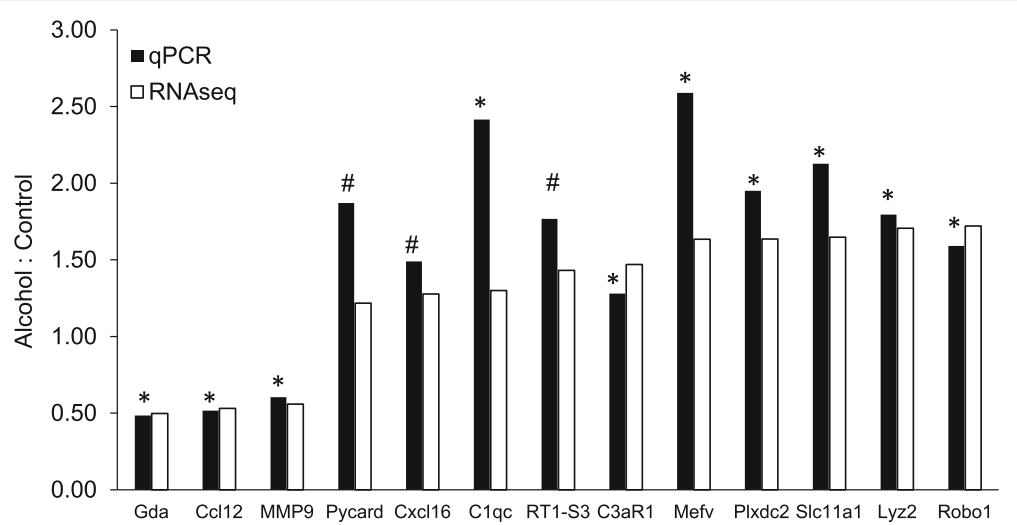

Fig. 2 Validation of RNAseq results. Reverse transcriptase quantitative PCR (qPCR) was used to measure mRNA levels of the indicated Alc-DEs. qPCR was carried out in samples from microglia incubated for $24 \mathrm{~h}$ with nothing (control, $n=3)$ or $75 \mathrm{mM}$ ethanol $(n=3)$, and results normalized to values measured for $\beta$-actin in the same samples. The $y$-axis shows the ratio of the average mRNA level measured in the ethanol versus the control samples (filled bars) and is plotted next to the fold-difference calculated from RNAseq data (open bars). For qPCR results, ${ }^{*} P<0.05$; ${ }^{\#} P<$ 0.10 control vs alcohol. For the RNAseq data, all DEs were found significantly different using Deseq2

of complement protein $\mathrm{C} 1 \mathrm{q}$, as well as 7 other mRNAs (Oas1b, Rtp4, Ifih1, Pou2f2, Kdelr1, Coro1a, and Ddx58) involved in immune effector responses. There are four KEGG pathways identified in the group of 885 Alc*TIIDEs (Additional file 1: Table S5B), three of which involve RNA handling (ribosome, spliceosome, and transport) and one involves Salmonella infection. Interestingly, while levels of 14 of the 18 mRNAs encoding nuclear ribosomal subunits were decreased, the levels of 7 of the 8 mRNAs encoding mitochondrial ribosomal subunits were increased.

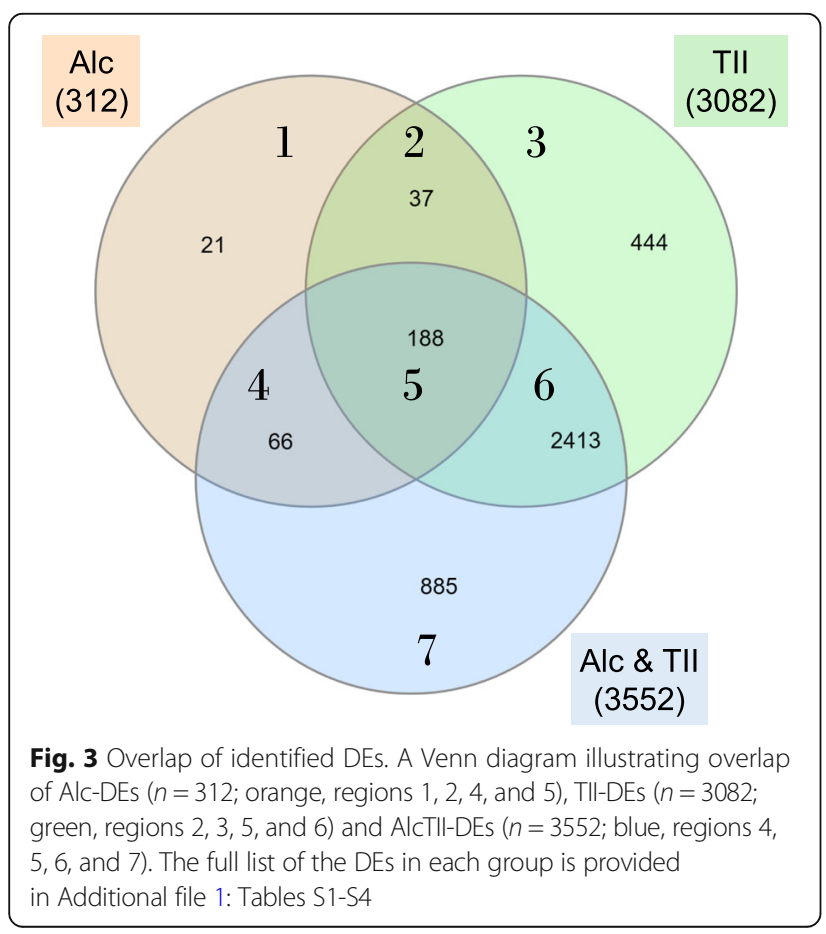

\section{Alcohol reduces microglial phagocytosis}

Since phagocytosis was one of the highest KEGG pathways identified in the Alc-DE group, we tested if alcohol influenced microglial phagocytosis. In primary rat microglial cells, overnight exposure to alcohol reduced phagocytosis of fluorescently labeled oligomeric $A \beta_{1-42}$ (Fig. 4a, b). In these cells, incubation with TII cytokines also reduced $A \beta$ phagocytosis compared to control cells, but that reduction was not affected by the presence of alcohol (Fig. 4c, d). Quantitation of the average amount of $A \beta$ internalized over 45 min shows a significant $16 \%$ reduction due to alcohol and a $37 \%$ reduction due to TII (Fig. 4e).

\section{Discussion}

Several studies have examined the effects of alcohol consumption on neuroinflammatory gene expression. Transcript profiling has been carried out using RNA from the whole brain of mice fed alcohol $4 \mathrm{~h}$ per day for 4 days [4]; from amygdala (AMY) after 30 days drinking using a 2-bottle choice [21]; from prefrontal cortex (PFC) after chronic (30 day), chronic intermittent (every other day for 29 days) or drinking in the dark (DID, $4 \mathrm{~h}$ in the dark for 36 days) [22]; and from PFC, Nucleus Accumbens (NAC), and AMY after 4 weekly cycles of chronic intermittent drinking [23]. In these studies, pathway analysis identified enrichment for many microglial mRNAs and networks, consistent with a role for microglia activation by alcohol. In microglia acutely isolated from prefrontal cortex of mice after alcohol consumption for 60 days in an every-other day drinking paradigm [24], 1010 Alc-DEs were identified in the microglial samples, compared to 2461 in total homogenates. Of the 1010 DEs, 846 were unique to microglia and not detected in the total homogenates. Similar to our findings, the largest 

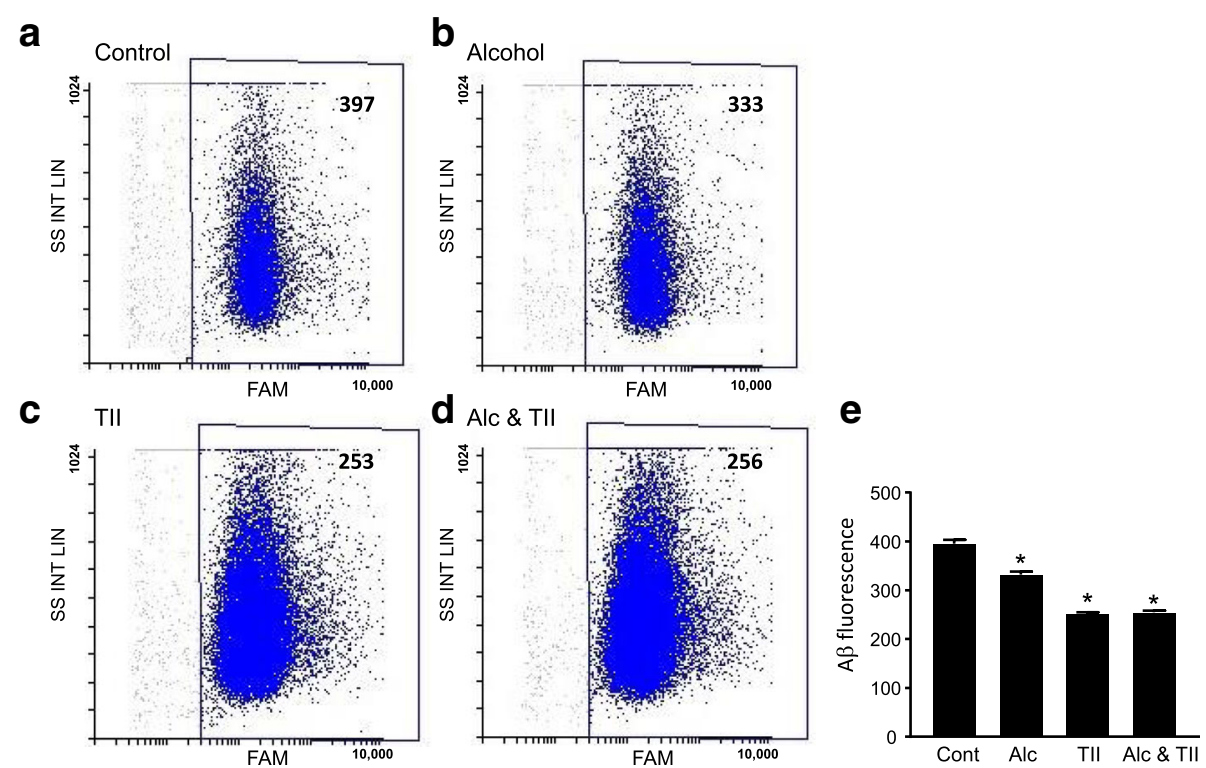

Fig. 4 Alcohol reduces amyloid beta phagocytosis in rat microglia. Primary rat microglia were incubated overnight with a nothing (control), b $75 \mathrm{mM}$ ethanol, c TII, or d $75 \mathrm{mM}$ ethanol and TII. The next day, the cells were assayed by flow cytometry for phagocytosis of FAM-labeled oligomeric $A \beta_{1-42}$. e Average internalized FAM fluorescence per cell. Data is from 3 different batches of microglial cells totaling 9197 (controls), 8976 (alcohol), 24,588 (TII), and 28,773 (Alc * TII) events. * $P<0.005$ versus control cells, one-way ANOVA, Tukey's post hoc analysis

differences were less than twofold for the DEs. Overall, comparison of the 846 alcohol-induced microglial specific changes to the 312 Alc-DEs identified in the current study showed only 28 overlapping mRNAs. Whether this large difference reflects the long duration of the in vivo paradigm compared to a relatively brief $24 \mathrm{~h}$ period of in vitro exposure or to differences between acutely isolated microglia to primary microglial prepared from mixed glial cultures is not known.

In our study, the average change in the 313 Alc-DEs was $16 \%$, ranging from a $50 \%$ decrease to a $72 \%$ increase. While modest, these changes are consistent with those reported for microglial transcripts in other studies. In enriched microglia isolated from CTX of alcohol-fed rats [24], the majority of DEs had expression changes between $\log 2$ of $0.125(9 \%)$ and 0.375 (30\%); changes for the total cortical homogenates were somewhat greater, ranging from $\log 2$ of $0.10(7 \%)$ to about $0.5(50 \%)$. In a study of microRNAs, the analysis for DEs used cutoff thresholds of 5\% [23], and in a study of synaptosomal transcripts [21], the majority of transcripts showed fold changes on the order of $20 \%$ or less. These changes are consistent with reports that modest differences in alcohol-induced gene expression are common for CNS [44]. These observations suggest that modest changes in a set of functionally related mRNAs (and associated proteins) can exert as significant an effect as does a robust change in expression of a single transcript.

In addition to identification of genes altered by alcohol use, studies have been carried out in rodent [45-48] and human samples to identify gene expression patterns that correlate with alcohol use or preference [49-52]. A comparative network analysis of RNAseq data from rats bred for either high (SHR) or low (BN-LX) alcohol preference, and by including correlation to phenotypic data from a recombinant inbred population, allowed identification of candidate genes associated with alcohol consumption [47], many of which were known to be expressed in microglia (or astrocytes). Analysis of RNA from brain regions of alcoholic compared to nonalcoholic patients have identified patterns of gene expression that discriminate between groups [51, 52]. In the nucleus accumbens of patients with alcohol dependency, over 4500 transcripts were identified as being differentially expressed, which could be clustered into 24 mRNA co-expression networks of which 6 were significantly correlated with dependency [52] and 4 were enriched for glial transcripts. However, in these cases, it is not known if expression changes were direct consequences of alcohol, or secondary to alcohol-induced damage.

In our studies, pathway analysis using DAVID [41] and GO Consortium [42, 43] platforms identified 5 KEGG pathways enriched in the 312 Alc-DE group, with phagosome being one of highest including transcripts for Atp6ap1, C3, Calr, Cd300lf, Coro1a, Ctss, Cyba, Fcgr1a, Itgb5, Mfge8, Ncf1, Psap, Pycard, RT1-A1, RT1-CE14, RT1-N3, RT1-S3, Sirpa, Slc11a1, and Tlr2. Many of these genes regulate the processes of phagocytosis and degradation (Table 1). In addition, we found that alcohol 
Table 1 Phagosome-related mRNA enriched in alcohol-treated microglia

\begin{tabular}{|c|c|}
\hline Symbol & Name and function \\
\hline \multirow[t]{2}{*}{ Corola } & Coronin1a \\
\hline & $\begin{array}{l}\text { Cell membrane associated protein that interacts } \\
\text { with actin filaments to facilitate cell motility, } \\
\text { endocytosis, and phagocytosis. Loss of Corola } \\
\text { expression or ability to bind to F-actin impairs } \\
\text { these processes [53]. }\end{array}$ \\
\hline \multirow[t]{2}{*}{ ATP6ар1 } & ATPase $\mathrm{H}+$ transporting accessory protein 1 \\
\hline & $\begin{array}{l}\text { Component of the } \mathrm{H}+\text { transporting vacuolar } \\
\text { ATPase present in phagosomes [54] }\end{array}$ \\
\hline \multirow[t]{2}{*}{ Fcgr1a } & Fc fragment of lgG receptor la \\
\hline & $\begin{array}{l}\text { Complexes with leukotriene B4 receptor in } \\
\text { lipid rafts, enhances macrophage anti- } \\
\text { microblial actions [55] }\end{array}$ \\
\hline RT1 & $\begin{array}{l}\text { Proteins of the MHC class I family, involved in } \\
\text { antigen presentation. }\end{array}$ \\
\hline \multirow[t]{2}{*}{ Ctss } & Cathepsin S \\
\hline & $\begin{array}{l}\text { Peptidase present in phagolysosomes where it } \\
\text { degrades various target proteins [56] }\end{array}$ \\
\hline Cyba & Cytochrome b-245 alpha chain \\
\hline \multirow[t]{2}{*}{ Ncf1 } & Neutrophil cytosolic factor 1 \\
\hline & $\begin{array}{l}\text { Components of the NADPH Oxidase complex, } \\
\text { present in phagolysomes. }\end{array}$ \\
\hline \multirow[t]{2}{*}{ Slc11a1 } & $\begin{array}{l}\text { Solute carrier family } 11 \text { member a1, also referred } \\
\text { to as Nramp1 }\end{array}$ \\
\hline & $\begin{array}{l}\text { Transmembrane phagosomal divalent cation } \\
\text { transporter [57] }\end{array}$ \\
\hline \multirow[t]{2}{*}{ Mfge8 } & Ligand milk fat globule EGF factor-8 \\
\hline & $\begin{array}{l}\text { Ligand for Itgb5 (integrain subunit beta 5) required for } \\
\text { activation of several pathways, including MerTK activation } \\
\text { and F-actin recruitment, involved in clearance [58] }\end{array}$ \\
\hline \multirow[t]{2}{*}{ Psap } & Prosaponin \\
\hline & $\begin{array}{l}\text { Precursor of saposins A, B, C, and D, which have } \\
\text { roles in lysomal degradation pathways [59] }\end{array}$ \\
\hline \multirow[t]{2}{*}{ Sirpa } & Signal regulatory protein alpha \\
\hline & $\begin{array}{l}\text { Macrophage receptor for CD47 which is a broad } \\
\text { inhibitor of phagocytosis }[60,61]\end{array}$ \\
\hline \multirow[t]{2}{*}{ Calr } & Calreticulin \\
\hline & $\begin{array}{l}\text { When present on the cell surface acts as a signal } \\
\text { to activate macrophage phagocytosis [62] }\end{array}$ \\
\hline \multirow[t]{2}{*}{ CD300lf } & Member of the CD300 receptor family \\
\hline & $\begin{array}{l}\text { Roles in activating macrophage engulfment by } \\
\text { phosphatidylserine signaling [63] }\end{array}$ \\
\hline \multirow[t]{2}{*}{ Pycard } & $\begin{array}{l}\text { PYD And CARD Domain Containing, also referred } \\
\text { to as ASC (Apoptosis-Associated Speck-Like) }\end{array}$ \\
\hline & $\begin{array}{l}\text { Component of the NLRP3 inflammasome, recently } \\
\text { shown to play a role in amyloid deposition. [64] }\end{array}$ \\
\hline
\end{tabular}

increased levels of several complement transcripts, including C1qa,b, and c; C3; and C3aR1, and moreover that the $\mathrm{C} 1 \mathrm{q}$ variants were not increased by TII alone.
This is consistent with studies showing that alcohol increases complement proteins, including $\mathrm{C} 1 \mathrm{q}, \mathrm{C} 3 \mathrm{a}, \mathrm{C} 5 \mathrm{a}$, $\mathrm{C} 3 \mathrm{aR}$, and $\mathrm{C} 5 \mathrm{aR}$, in liver $[65,66]$ and adipose tissue [67]. Since microglial complement activation can cause neuronal damage [68], these findings suggest that $\mathrm{C} 1 \mathrm{q}$ induction in the brain could contribute to alcoholinduced neuropathology. While this may be mediated through activation of the complement pathways, observations that several complement proteins, including $\mathrm{C} 1 \mathrm{q}$ and C3b promote phagocytosis $[69,70]$ and that CR3 regulates amyloid clearance [71-74], suggests that alcohol-induced changes in complement expression may also regulate microglial phagocytosis of amyloid.

Our results demonstrate that microglial phagocytosis of $A \beta_{1-42}$ is significantly suppressed following 1 -day exposure to $75 \mathrm{mM}$ ethanol. This dose of ethanol is in the high range and is attained in human following binge drinking or in heavy drinkers. Similar doses have previously been used to study phagocytosis in vitro [33, 36]. Suppressive effects of alcohol on phagocytosis have previously been reported in studies examining macrophages (see [35] for review). Alcohol reduces uptake of Pseudomonas aeruginosa [36], and of Candida albicans [75], and inhibition can be seen as soon as $1 \mathrm{~h}$ after treatment with ethanol [76]. In contrast to macrophages, there are limited studies of the effects of alcohol exposure on microglial phagocytosis. In neonatal mice [77], acute binge-like alcohol exposure induced microglial activation and phagocytosis of damaged neurons, suggesting that acute ethanol exposure could be protective during early development. It was also shown using a similar acute exposure model, that although activated microglia were observed near to dead cells in the cortex, that apoptotic bodies accumulated, interpreted that the rate of cell death exceeded microglial clearance capacity [78]. In embryonic stem cell-derived microglia [79], 48-h exposure to $100 \mathrm{mM}$ ethanol decreased phagocytosis of fluorescently labeled E. coli particles by $15 \%$ compared to control cells. These findings are consistent with the ability of alcohol to inhibit microglia in vivo.

In our studies, alcohol exposure reduced phagocytosis of $A \beta$ with no effect on uptake of polystyrene beads (unpublished findings, DLF). $\mathrm{A} \beta$ phagocytosis is regulated by various proteins several of which were identified as being induced by alcohol treatment. In primary microglia, activation of SIRPb1 (signal regulatory protein beta1 ) increased phagocytosis of fibrillary $A \beta$, as well as of microsphere beads [80]. In contrast, inhibition of CLIC1 (chloride intracellular ion channel) increased $\mathrm{A} \beta$ phagocytosis, possibly via suppression of pro-inflammatory cytokine or iNOS induction [81], while inhibition had no effect on bead uptake. The basis for this difference is not known, but may be related to the ability of $A \beta$ but not 
polystyrene beads to induce microglia cytokine production, which in turn regulates phagocytotic activities.

Alcohol consumption is generally considered a risk factor for dementia, although there are some inconsistencies which may depend upon age, gender, amounts consumed, and numerous other genetic and environmental factors. Indications that alcohol can worsen or accelerate dementia may contribute to the risk or progression AD; however, those studies do not address if alcohol specifically modifies AD pathogenesis. Analysis of 125 brain autopsy samples showed that, as expected, higher $A \beta$ immunoreactivity $(A \beta-I R)$ was associated with increased age and ApoE4 allele [82]. However, A $\beta$-IR was significantly inversely associated with beer drinking with an odds ratio close to 0.35 , although the significance was reduced when stratified for age and ApoE4 [82]. Epidemiological studies report a reduction in $\mathrm{AD}$ prevalence due to low alcohol ingestion, and protective effects in those having moderate consumption [30]. Similarly, a prospective study of over 3000 subjects over 3 years found that light to moderate alcohol consumption reduced the risk of overall dementia by about $30 \%$ [83]. In contrast, a recent review of the literature to determine if alcohol consumption is a risk factor for AD concluded that alcohol use causes cognitive impairment by contributing to the neurodegenerative processes [84]. A systematic review concluded that there is as yet no consensus on this issue and that despite several studies, alcohol should not be considered methods to reduce AD risk [85].

In contrast, evidence that alcohol can increase amyloid levels comes from several studies. In vitro, low ethanol exposure, equivalent to moderate alcohol usage, decreased $A \beta$ binding to neurons and thereby reduced neurotoxic actions of $A \beta$ [86] which may account for protective actions at low to moderate doses. Exacerbation of $\mathrm{AD}$ pathogenesis by alcohol has been reported using both in vitro and in vivo studies. In human, SK-NMC neuroblastoma cells ethanol upregulated BACE1 expression and $A \beta$ production, as well as increased reactive oxygen species (ROS) production, cyclooxygenase-2 (COX-2) expression and $\mathrm{PGE}_{2}$ production [32]. Ethanol exposure of mice for 4 weeks increased APP levels and BACE1 expression, promoted $A \beta$ production, increased plaque deposition, and worsened cognitive deficits [33]. Adult rats fed alcohol for 5 weeks had increased levels of APP and BACE1 in several brain regions and increased presenilin-1 and nicastrin in the hippocampus [34]. Longterm alcohol consumption significantly impaired spatial memory in adult rats, which may be a contributing factor to development of AD [87]. These findings show that alcohol increases amyloidogenic processing, a mechanism which could contribute to plaque burden. However, it is not known if increases in plaque numbers were dependent on reduced microglial activities (e.g., phagocytosis) which otherwise could compensate for increased $A \beta$ production.

The current findings have several limitations, a primary one being that these studies were done using enriched cultures of primary rat microglia, which differ from acutely isolated brain microglia in terms of gene expression and function. It is therefore important that analogous studies be carried out to test the effects of alcohol consumption on the microglial transcriptome, and on amyloid phagocytosis, in a transgenic mouse model of amyloid deposition. Second, we only evaluated effects of a single acute exposure to ethanol, which likely will differ from effects following chronic exposure. Since alcohol consumption in humans can involve periods of consumption followed by periods of withdrawal, it is important to determine how withdrawal influences microglial gene expression and phagocytosis.

\section{Conclusion}

These results define the changes that occur to microglial cells following exposure to physiologically relevant amounts of ethanol. While changes in inflammatory mRNAs were expected, observations that alcohol induces changes in mRNAs involved in phagocytosis including members of the complement system is a novel finding suggesting that alcohol consumption can lead to dysregulation of clearance processes in the CNS. In vitro results showing reduced uptake of $A \beta$, together with the finding that alcohol increase Pycard (ASC) expression which can play a role in amyloid plaque formation, have important implications for $\mathrm{AD}$ patients as well as those at risk to develop disease.

\section{Additional file}

Additional file 1: Table S1. Differentially expressed mRNAs due to alcohol treatment "Alc-DEs". Shading indicates mRNA levels were confirmed by qPCR. Table S2 Differentially expressed mRNAs due to TII treatment "TII-DEs". Table S3 Differentially expressed mRNAs due to alcohol and TII treatment "AlcTII-DEs". Table S4 Treatment-group overlap of differentially expressed mRNAs. Grey, involved in immune effector responses; Blue, mitochondrial ribosomal subunit; Orange, nuclear ribosomal subunit. Table S5 KEGG pathways identified in treatment groups. Table S6 FPKM (fragments per kilobase of transcript per million fragments mapped). (ZIP $3000 \mathrm{~kb})$

\section{Abbreviations}

AD: Alzheimer's disease; Alc*-DEs: DEs induced by alcohol or alcohol plus TII, but not by TIl alone; Alc-DEs: DEs induced by alcohol treatment; AlcInf-DEs: DEs only induced by alcohol plus TII treatment; AlcOnly-DEs: DEs only induced by alcohol alone; AlcTII-DEs: DEs induced by alcohol plus TII treatment; AMY: Amygdala; APP: Amyloid precursor protein; DE: Differentially expressed; DID: Drinking in the dark; DMEM: Dulbecco's modified Eagle's media; ERCC: External RNA Controls Consortium; FACS: Flow activated cell sorting; FAM: 6-Carboxyfluorescein; GO: Gene ontology; IFNy: Interferon gamma; IL1B: Interleukin 1-beta; NAC: Nucleus accumbens; PFC: Prefrontal cortex; qPCR: Quantitative reverse-transcription PCR; RNAseq: RNA sequencing; ROS: Reactive oxygen species; TII: Mixture of IL1 $\beta$, IFNY, and TNFa; TII-DEs: DEs induced by TIl treatment; TNFa : Tumor necrosis factor alpha 


\section{Funding}

This work was supported in part by grant NIAAA P50AA-022538 (SCP) and a Research Career Scientist award from the Department of Veterans Affairs (DLF and SCP).

\section{Availability of data and materials}

All data generated or analyzed during this study are included in this published article and its additional files.

\section{Authors' contributions}

SK performed the RNAseq studies and qPCRs. MG-P and HS performed the phagocytosis assays. LL performed the nitrite assays. HK performed the GPCR verifications. MTH and JLMM designed the phagocytosis assays. SCP conceived the design of alcohol treatments and RNAseq experiments. DLF conceived the design of experiments, collected and analyzed the data, and wrote the manuscript. All authors read and approved the final manuscript.

\section{Ethics approval}

All experiments were conducted with approval of the University of Illinois Institutional Animal Care and Use Committee (protocol number 15-129).

\section{Competing interests}

The authors declare that they have no competing interests

\section{Publisher's Note}

Springer Nature remains neutral with regard to jurisdictional claims in published maps and institutional affiliations.

\section{Author details}

'Department of Anesthesiology, University of Illinois at Chicago, Chicago, IL 60612, USA. ²Department of Pharmacology, University Complutense, Centro de Investigacion Biomedica en Red de Salud Mental (CIBERSAM), Madrid 28040, Spain. ${ }^{3}$ Department of Neurodegenerative Disease and Geriatric Psychiatry, University of Bonn, 53127 Bonn, Germany. ${ }^{4}$ Institute of Pharmacology, Catholic University Medical School, 00168 Rome, Italy. ${ }^{5}$ Center for Alcohol Research in Epigenetics, Department of Psychiatry, University of Illinois at Chicago, Chicago, IL 60612, USA. 'Department of Veterans Affairs, Jesse Brown VA Medical Center, Chicago, IL 60612, USA.

\section{Received: 25 April 2018 Accepted: 29 April 2018}

\section{Published online: 14 May 2018}

\section{References}

1. Robinson G, Most D, Ferguson LB, Mayfield J, Harris RA, Blednov YA. Neuroimmune pathways in alcohol consumption: evidence from behavioral and genetic studies in rodents and humans. Int Rev Neurobiol. 2014;118:13-39.

2. Warden A, Erickson E, Robinson G, Harris RA, Mayfield RD. The neuroimmune transcriptome and alcohol dependence: potential for targeted therapies. Pharmacogenomics. 2016:17:2081-96.

3. Crews FT, Lawrimore CJ, Walter TJ, Coleman LG Jr. The role of neuroimmune signaling in alcoholism. Neuropharmacology. 2017;122:56-73.

4. Agrawal RG, Hewetson A, George CM, Syapin PJ, Bergeson SE. Minocycline reduces ethanol drinking. Brain Behav Immun. 2011;25(Suppl 1):S165-9.

5. Wu Y, Lousberg EL, Moldenhauer LM, Hayball JD, Robertson SA, Coller JK, Watkins LR, Somogyi AA, Hutchinson MR. Attenuation of microglial and IL-1 signaling protects mice from acute alcohol-induced sedation and/or motor impairment. Brain Behav Immun. 2011;25(Suppl 1):S155-64.

6. Martinez JM, Groot JA, Curtis DC, Allison CL, Marquardt PC, Holmes AN, Edwards DS, Trotter DR, Syapin PJ, Finn DA, Bergeson SE. Effective reduction of acute ethanol withdrawal by the tetracycline derivative, tigecycline, in female and male DBA/2J mice. Alcohol Clin Exp Res. 2016;40:2499-505.

7. Blanco AM, Pascual M, Valles SL, Guerri C. Ethanol-induced iNOS and COX-2 expression in cultured astrocytes via NF-kappa B. Neuroreport. 2004;15:681-5.

8. Alfonso-Loeches S, Urena-Peralta J, Morillo-Bargues MJ, Gomez-Pinedo U, Guerri C. Ethanol-induced TLR4/NLRP3 neuroinflammatory response in microglial cells promotes leukocyte infiltration across the BBB. Neurochem Res. 2016:41:193-209.

9. Alfonso-Loeches S, Pascual-Lucas M, Blanco AM, Sanchez-Vera I, Guerri C. Pivotal role of TLR4 receptors in alcohol-induced neuroinflammation and brain damage. J Neurosci. 2010;30:8285-95.
10. Fernandez-Lizarbe S, Pascual M, Guerri C. Critical role of TLR4 response in the activation of microglia induced by ethanol. J Immunol. 2009;183:4733-44.

11. Fernandez-Lizarbe S, Pascual M, Gascon MS, Blanco A, Guerri C. Lipid rafts regulate ethanol-induced activation of TLR4 signaling in murine macrophages. Mol Immunol. 2008;45:2007-16.

12. Blanco $A M$, Guerri C. Ethanol intake enhances inflammatory mediators in brain: role of glial cells and TLR4/IL-1RI receptors. Front Biosci. 2007;12:2616-30.

13. Valles SL, Blanco AM, Pascual M, Guerri C. Chronic ethanol treatment enhances inflammatory mediators and cell death in the brain and in astrocytes. Brain Pathol. 2004;14:365-71.

14. Fernandez-Lizarbe S, Montesinos J, Guerri C. Ethanol induces TLR4/TLR2 association, triggering an inflammatory response in microglial cells. J Neurochem. 2013;126:261-73.

15. Pandey SC. TLR4-MyD88 signalling: a molecular target for alcohol actions. $\mathrm{Br}$ J Pharmacol. 2012:165:1316-8.

16. Blanco AM, Valles SL, Pascual M, Guerri C. Involvement of TLR4/type I IL-1 receptor signaling in the induction of inflammatory mediators and cell death induced by ethanol in cultured astrocytes. J Immunol. 2005;175:6893-9.

17. Montesinos J, Alfonso-Loeches S, Guerri C. Impact of the innate immune response in the actions of ethanol on the central nervous system. Alcohol Clin Exp Res. 2016;40:2260-70.

18. Gustot T, Lemmers A, Moreno C, Nagy N, Quertinmont E, Nicaise C, Franchimont D, Louis H, Deviere J, Le Moine O. Differential liver sensitization to toll-like receptor pathways in mice with alcoholic fatty liver. Hepatology. 2006;43:989-1000.

19. Lippai D, Bala S, Petrasek J, Csak T, Levin I, Kurt-Jones EA, Szabo G. Alcoholinduced IL-1beta in the brain is mediated by NLRP3/ASC inflammasome activation that amplifies neuroinflammation. J Leukoc Biol. 2013;94:171-82.

20. Crews FT, Qin L, Sheedy D, Vetreno RP, Zou J. High mobility group box 1/ toll-like receptor danger signaling increases brain neuroimmune activation in alcohol dependence. Biol Psychiatry. 2013;73:602-12.

21. Most D, Leiter C, Blednov YA, Harris RA, Mayfield RD. Synaptic microRNAs coordinately regulate synaptic mRNAs: perturbation by chronic alcohol consumption. Neuropsychopharmacology. 2016;41:538-48.

22. Osterndorff-Kahanek E, Ponomarev I, Blednov YA, Harris RA. Gene expression in brain and liver produced by three different regimens of alcohol consumption in mice: comparison with immune activation. PLoS One. 2013;8:e59870.

23. Osterndorff-Kahanek EA, Tiwari GR, Lopez MF, Becker HC, Harris RA, Mayfield RD. Long-term ethanol exposure: temporal pattern of microRNA expression and associated mRNA gene networks in mouse brain. PLoS One. 2018;13: e0190841.

24. McCarthy GM, Farris SP, Blednov YA, Harris RA, Mayfield RD. Microglialspecific transcriptome changes following chronic alcohol consumption. Neuropharmacology. 2018;128:416-24.

25. Venegas $C$, Kumar S, Franklin BS, Dierkes T, Brinkschulte R, Tejera D, Vieira-Saecker A, Schwartz S, Santarelli F, Kummer MP, et al. Microglia-derived ASC specks crossseed amyloid-beta in Alzheimer's disease. Nature. 2017;552:355-61.

26. Ries M, Sastre M. Mechanisms of Abeta clearance and degradation by glial cells. Front Aging Neurosci. 2016;8:160.

27. Zuroff L, Daley D, Black KL, Koronyo-Hamaoui M. Clearance of cerebral Abeta in Alzheimer's disease: reassessing the role of microglia and monocytes. Cell Mol Life Sci. 2017;74:2167-201.

28. Hersi M, Irvine B, Gupta P, Gomes J, Birkett N, Krewski D. Risk factors associated with the onset and progression of Alzheimer's disease: a systematic review of the evidence. Neurotoxicology. 2017;61:143-87.

29. Heymann D, Stern Y, Cosentino S, Tatarina-Nulman O, Dorrejo JN, Gu Y. The association between alcohol use and the progression of Alzheimer's disease. Curr Alzheimer Res. 2016;13:1356-62.

30. Huang WJ, Zhang X, Chen WW. Association between alcohol and Alzheimer's disease. Exp Ther Med. 2016;12:1247-50.

31. Luchsinger JA, Tang MX, Siddiqui M, Shea S, Mayeux R. Alcohol intake and risk of dementia. J Am Geriatr Soc. 2004;52:540-6.

32. Gabr AA, Lee HJ, Onphachanh X, Jung YH, Kim JS, Chae CW, Han HJ. Ethanol-induced PGE2 up-regulates Abeta production through PKA/CREB signaling pathway. Biochim Biophys Acta. 1863;2017:2942-53.

33. Huang D, Yu M, Yang S, Lou D, Zhou W, Zheng L, Wang Z, Cai F, Zhou W, Li T, Song W. Ethanol alters APP processing and aggravates Alzheimerassociated phenotypes. Mol Neurobiol. 2017. https://doi.org/10.1007/ s12035-017-0703-3.

34. Kim SR, Jeong HY, Yang S, Choi SP, Seo MY, Yun YK, Choi Y, Baik SH, Park JS, Gwon AR, et al. Effects of chronic alcohol consumption on expression levels of APP and Abeta-producing enzymes. BMB Rep. 2011;44:135-9. 
35. Karavitis J, Kovacs EJ. Macrophage phagocytosis: effects of environmental pollutants, alcohol, cigarette smoke, and other external factors. J Leukoc Biol. 2011;90:1065-78.

36. Karavitis J, Murdoch EL, Deburghgraeve C, Ramirez L, Kovacs EJ. Ethanol suppresses phagosomal adhesion maturation, Rac activation, and subsequent actin polymerization during FcgammaR-mediated phagocytosis. Cell Immunol. 2012;274:61-71.

37. Madrigal $\mathrm{J}$, Feinstein DL, Dello Russo C. Norepinephrine protects cortical neurons against microglial-induced cell death. J Neurosci Res. 2005;81:390-6.

38. Dobin A, Davis CA, Schlesinger F, Drenkow J, Zaleski C, Jha S, Batut P, Chaisson M, Gingeras TR. STAR: ultrafast universal RNA-seq aligner. Bioinformatics. 2013;29:15-21.

39. Love Ml, Huber W, Anders S. Moderated estimation of fold change and dispersion for RNA-seq data with DESeq2. Genome Biol. 2014;15:550.

40. Chen Z, Liu J, Ng HK, Nadarajah S, Kaufman HL, Yang JY, Deng Y. Statistical methods on detecting differentially expressed genes for RNA-seq data. BMC Syst Biol. 2011;5(Suppl 3):S1.

41. Huang DW, Sherman BT, Tan Q, Collins JR, Alvord WG, Roayaei J, Stephens R, Baseler MW, Lane HC, Lempicki RA. The DAVID Gene Functional Classification Tool: a novel biological module-centric algorithm to functionally analyze large gene lists. Genome Biol. 2007;8:R183.

42. Ashburner M, Ball CA, Blake JA, Botstein D, Butler H, Cherry JM, Davis AP, Dolinski K, Dwight SS, Eppig JT, et al. Gene ontology: tool for the unification of biology. The Gene Ontology Consortium. Nat Genet. 2000;25:25-9.

43. The Gene Ontology Consortium. Expansion of the Gene Ontology knowledgebase and resources. Nucleic Acids Res. 2017;45:D331-d338.

44. Lovinger DM, Crabbe JC. Laboratory models of alcoholism: treatment target identification and insight into mechanisms. Nat Neurosci. 2005;8:1471-80.

45. Kimpel MW, Strother WN, McClintick JN, Carr LG, Liang T, Edenberg HJ, McBride WJ. Functional gene expression differences between inbred alcohol-preferring and -non-preferring rats in five brain regions. Alcohol. 2007:41:95-132.

46. Tabakoff B, Saba L, Kechris K, Hu W, Bhave SV, Finn DA, Grahame NJ, Hoffman PL. The genomic determinants of alcohol preference in mice. Mamm Genome. 2008;19:352-65.

47. Saba LM, Flink SC, Vanderlinden LA, Israel Y, Tampier L, Colombo G, Kiianmaa K, Bell RL, Printz MP, Flodman P, et al. The sequenced rat brain transcriptome-its use in identifying networks predisposing alcohol consumption. FEBS J. 2015;282:3556-78.

48. Carr LG, Kimpel MW, Liang T, McClintick JN, McCall K, Morse M, Edenberg $\mathrm{HJ}$. Identification of candidate genes for alcohol preference by expression profiling of congenic rat strains. Alcohol Clin Exp Res. 2007;31:1089-98.

49. Liu J, Lewohl JM, Harris RA, lyer VR, Dodd PR, Randall PK, Mayfield RD. Patterns of gene expression in the frontal cortex discriminate alcoholic from nonalcoholic individuals. Neuropsychopharmacology. 2006;31:1574-82.

50. Mayfield RD, Lewohl JM, Dodd PR, Herlihy A, Liu J, Harris RA. Patterns of gene expression are altered in the frontal and motor cortices of human alcoholics. J Neurochem. 2002;81:802-13.

51. Lewohl JM, Wang L, Miles MF, Zhang L, Dodd PR, Harris RA. Gene expression in human alcoholism: microarray analysis of frontal cortex. Alcohol Clin Exp Res. 2000;24:1873-82.

52. Mamdani M, Williamson V, McMichael GO, Blevins T, Aliev F, Adkins A, Hack L, Bigdeli $T$, van der Vaart AD, Web BT, et al. Integrating mRNA and miRNA weighted gene co-expression networks with eQTLs in the nucleus accumbens of subjects with alcohol dependence. PLoS One. 2015;10:e0137671.

53. Chan KT, Roadcap DW, Holoweckyj N, Bear JE. Coronin $1 \mathrm{C}$ harbours a second actin-binding site that confers co-operative binding to F-actin. Biochem J. 2012;444:89-96.

54. Jansen EJ, Martens GJ. Novel insights into V-ATPase functioning: distinct roles for its accessory subunits ATP6AP1/Ac45 and ATP6AP2/(pro) renin receptor. Curr Protein Pept Sci. 2012;13:124-33.

55. Serezani $\mathrm{CH}$, Aronoff DM, Sitrin RG, Peters-Golden M. FcgammaRI ligation leads to a complex with BLT1 in lipid rafts that enhances rat lung macrophage antimicrobial functions. Blood. 2009;114:3316-24.

56. Nakanishi H. Microglial functions and proteases. Mol Neurobiol. 2003;27: 163-76.

57. Montalbetti N, Simonin A, Kovacs G, Hediger MA. Mammalian iron transporters: families SLC11 and SLC40. Mol Asp Med. 2013;34:270-87.

58. Mao Y, Finnemann SC. Essential diurnal Rac1 activation during retinal phagocytosis requires alphavbeta5 integrin but not tyrosine kinases focal adhesion kinase or Mer tyrosine kinase. Mol Biol Cell. 2012;23:1104-14.
59. Sun Y, Grabowski GA. Altered autophagy in the mice with a deficiency of saposin A and saposin B. Autophagy. 2013;9:1115-6.

60. Alvey C, Discher DE. Engineering macrophages to eat cancer: from "marker of self" CD47 and phagocytosis to differentiation. J Leukoc Biol. 2017;102:31-40.

61. Weiskopf K. Cancer immunotherapy targeting the CD47/SIRPalpha axis. Eur J Cancer. 2017;76:100-9.

62. Daitoku S, Takenaka K, Yamauchi T, Yurino A, Jinnouchi F, Nunomura T, Eto T, Kamimura T, Higuchi M, Harada N, et al. Calreticulin mutation does not contribute to disease progression in essential thrombocythemia by inhibiting phagocytosis. Exp Hematol. 2016;44:817-825.e813.

63. Voss OH, Tian L, Murakami Y, Coligan JE, Krzewski K. Emerging role of CD300 receptors in regulating myeloid cell efferocytosis. Mol Cell Oncol. 2015;2:e964625

64. Couturier J, Stancu IC, Schakman O, Pierrot N, Huaux F, Kienlen-Campard P, Dewachter I, Octave JN. Activation of phagocytic activity in astrocytes by reduced expression of the inflammasome component ASC and its implication in a mouse model of Alzheimer disease. J Neuroinflammation. 2016;13:20.

65. Smathers RL, Chiang DJ, McMullen MR, Feldstein AE, Roychowdhury S, Nagy LE. Soluble IgM links apoptosis to complement activation in early alcoholic liver disease in mice. Mol Immunol. 2016;72:9-18.

66. Cohen Jl, Roychowdhury S, McMullen MR, Stavitsky AB, Nagy LE. Complement and alcoholic liver disease: role of $\mathrm{C} 1 \mathrm{q}$ in the pathogenesis of ethanol-induced liver injury in mice. Gastroenterology. 2010;139:664-74. 674.e661

67. Sebastian BM, Roychowdhury S, Tang H, Hillian AD, Feldstein AE, Stahl GL, Takahashi K, Nagy LE. Identification of a cytochrome P4502E1/Bid/C1qdependent axis mediating inflammation in adipose tissue after chronic ethanol feeding to mice. J Biol Chem. 2011;286:35989-97.

68. Bodea LG, Wang Y, Linnartz-Gerlach B, Kopatz J, Sinkkonen L, Musgrove R, Kaoma T, Muller A, Vallar L, Di Monte DA, et al. Neurodegeneration by activation of the microglial complement-phagosome pathway. J Neurosci. 2014;34:8546-56.

69. Conway Morris A, Kefala K, Wilkinson TS, Dhaliwal K, Farrell L, Walsh T, Mackenzie SJ, Reid H, Davidson DJ, Haslett C, et al. C5a mediates peripheral blood neutrophil dysfunction in critically ill patients. Am J Respir Crit Care Med. 2009;180:19-28.

70. Morris MR, Doull IJ, Dewitt S, Hallett MB. Reduced iC3b-mediated phagocytotic capacity of pulmonary neutrophils in cystic fibrosis. Clin Exp Immunol. 2005;142:68-75.

71. Czirr E, Castello NA, Mosher Kl, Castellano JM, Hinkson IV, Lucin KM, BaezaRaja B, Ryu JK, Li L, Farina SN, et al. Microglial complement receptor 3 regulates brain Abeta levels through secreted proteolytic activity. J Exp Med. 2017;214:1081-92.

72. Fu H, Liu B, Frost JL, Hong S, Jin M, Ostaszewski B, Shankar GM, Costantino IM, Carroll MC, Mayadas TN, Lemere CA. Complement component C3 and complement receptor type 3 contribute to the phagocytosis and clearance of fibrillar Abeta by microglia. Glia. 2012;60:993-1003.

73. Hong S, Beja-Glasser VF, Nfonoyim BM, Frouin A, Li S, Ramakrishnan S, Merry KM, Shi Q, Rosenthal A, Barres BA, et al. Complement and microglia mediate early synapse loss in Alzheimer mouse models. Science. 2016;352:712-6.

74. Choucair-Jaafar N, Laporte V, Levy R, Poindron P, Lombard Y, Gies JP. Complement receptor 3 (CD11b/CD18) is implicated in the elimination of beta-amyloid peptides. Fundam Clin Pharmacol. 2011;25:115-22.

75. Morland B, Morland J. Reduced Fc-receptor function in human monocytes exposed to ethanol in vitro. Alcohol Alcohol. 1984;19:211-7.

76. Zuiable A, Wiener $\mathrm{E}$, Wickramasinghe $\mathrm{SN}$. In vitro effects of ethanol on the phagocytic and microbial killing activities of normal human monocytes and monocyte-derived macrophages. Clin Lab Haematol. 1992;14:137-47.

77. Saito M, Chakraborty G, Hui M, Masiello K, Saito M. Ethanol-induced neurodegeneration and glial activation in the developing brain. Brain Sci. 2016;6:31.

78. Ahlers KE, Karacay B, Fuller L, Bonthius DJ, Dailey ME. Transient activation of microglia following acute alcohol exposure in developing mouse neocortex is primarily driven by BAX-dependent neurodegeneration. Glia. 2015;63: 1694-713.

79. Gofman L, Cenna JM, Potula R. P2X4 receptor regulates alcohol-induced responses in microglia. J Neurolmmune Pharmacol. 2014;9:668-78.

80. Gaikwad S, Larionov S, Wang Y, Dannenberg H, Matozaki T, Monsonego A, Thal DR, Neumann H. Signal regulatory protein-beta1: a microglial modulator of phagocytosis in Alzheimer's disease. Am J Pathol. 2009;175:2528-39. 
81. Paradisi S, Matteucci A, Fabrizi C, Denti MA, Abeti R, Breit SN, MalchiodiAlbedi F, Mazzanti M. Blockade of chloride intracellular ion channel 1 stimulates Abeta phagocytosis. J Neurosci Res. 2008;86:2488-98.

82. Kok EH, Karppinen TT, Luoto T, Alafuzoff I, Karhunen PJ. Beer drinking associates with lower burden of amyloid beta aggregation in the brain: Helsinki sudden death series. Alcohol Clin Exp Res. 2016;40:1473-8.

83. Weyerer S, Schaufele M, Wiese B, Maier W, Tebarth F, van den Bussche H, Pentzek M, Bickel H, Luppa M, Riedel-Heller SG. Current alcohol consumption and its relationship to incident dementia: results from a 3-year follow-up study among primary care attenders aged 75 years and older. Age Ageing. 2011;40:456-63.

84. Venkataraman A, Kalk N, Sewell G, Ritchie CW, Lingford-Hughes A. Alcohol and Alzheimer's disease-does alcohol dependence contribute to betaamyloid deposition, neuroinflammation and neurodegeneration in Alzheimer's disease? Alcohol Alcohol. 2017:52:151-8.

85. Piazza-Gardner AK, Gaffud TJ, Barry AE. The impact of alcohol on Alzheimer's disease: a systematic review. Aging Ment Health. 2013;17:133-46.

86. Munoz G, Urrutia JC, Burgos CF, Silva V, Aguilar F, Sama M, Yeh HH, Opazo C, Aguayo LG. Low concentrations of ethanol protect against synaptotoxicity induced by Abeta in hippocampal neurons. Neurobiol Aging. 2015;36:845-56.

87. Ehrlich D, Pirchl M, Humpel C. Effects of long-term moderate ethanol and cholesterol on cognition, cholinergic neurons, inflammation, and vascular impairment in rats. Neuroscience. 2012;205:154-66.

Ready to submit your research? Choose BMC and benefit from:

- fast, convenient online submission

- thorough peer review by experienced researchers in your field

- rapid publication on acceptance

- support for research data, including large and complex data types

- gold Open Access which fosters wider collaboration and increased citations

- maximum visibility for your research: over $100 \mathrm{M}$ website views per year

At BMC, research is always in progress.

Learn more biomedcentral.com/submissions 